ఠ

\title{
Analysis of the cumulative effect of schizophrenia- related single nucleotide polymorphisms
}

This article was published in the following Dove Press journal:

Neuropsychiatric Disease and Treatment

12 June 2014

Number of times this article has been viewed

\author{
Roberto Lozano' \\ Reyes Marín ${ }^{2}$ \\ Isabel Freire ${ }^{2}$ \\ María-Jesús Santacruz ${ }^{2}$ \\ Asunción Pascual-García ${ }^{2}$ \\ 'Pharmacy Department, ${ }^{2}$ Psychiatry \\ Department, Hospital Real de \\ Nuestra Señora de Gracia, \\ Zaragoza, Spain
}

\section{Dear editor}

It is currently believed that predisposition for schizophrenia stems from the combined effect of multiple common polymorphisms. Thus, no genetic variant is considered to be fully responsible for the disease. ${ }^{1}$ For this reason, analysis of the cumulative effect of schizophrenia-related single nucleotide polymorphisms (SNPs) could provide information about the genetic mechanisms that underlie susceptibility.

Therefore, we have evaluated 100 common SNPs that were previously identified in schizophrenic patients by Need et al. ${ }^{1}$ In particular, we analyzed the percentage of exchange associated with these various polymorphisms, obtaining the following rates for minor alleles: $\mathrm{T}(39 \%), \mathrm{C}(22 \%), \mathrm{A}(21 \%)$, and $\mathrm{G}(18 \%)\left[\chi^{2}=14.4 ; \mathrm{df}=3 ; P=0.0024\right]$. Moreover, our investigation revealed the following data with regard to rates for major alleles: C (34\%), G (26\%), T (21\%), and A (19\%) [ $\left.\chi^{2}=25.84 ; \mathrm{df}=4 ; P<0.0001\right]$.

Subsequently, we compared these nucleotide exchange rates with the percentage of bases utilized in the codons of the genetic code, which correspond to the 20 standard amino acids upon translation. ${ }^{2}$

Based on this comparison, we propose three main hypotheses. First of all, the approximate doubling in the percentage of $\mathrm{T}(39 \%)$ as a substitute base results from additional $\mathrm{T} / \mathrm{U}$ exchanges that occur during DNA to RNA transcription (and vice versa). Secondly, the location of most of these SNPs within intergenic and intronic (92\%) regions implies that they are contained within non-coding RNAs (ncRNAs). ${ }^{3}$ Among other functions, these ncRNAs may participate in the control and/or regulation of RNA splicing (creating new splicing patterns) and DNA transcription (RNA-mediated, creating new transposition patterns). Finally, our codonic analysis led us to hypothesize that these SNPs primarily affect proline-containing protein isotypes (ie, $\mathrm{C}$ is the most often replaced nucleotide, and codons corresponding to the amino acid proline display the highest proportion of C). ${ }^{2}$

Proline motifs are frequently found in several members of the postsynaptic density (PSD) interactome, as well as several neurological and immunological proteins, such as carrier, accessory, adapter, and binding synapse proteins. Indeed, various intracellular signaling pathways could be affected by alterations in proline composition, including the following examples:

1. Opioid agonists mediate Toll-like receptor 4 (TLR4) signaling through the myeloid differentiation primary response gene-88 (MyD88)-dependent pathway, which employs a proline-rich Src homology-3 (SH3)-binding motif in order to efficiently couple lipopolysaccharide (LPS) engagement by TLR4 to Src family kinase (SFK) activation. In contrast, the MyD88-independent pathway requires
Correspondence: Roberto Lozano Pharmacy Department, Hospital Real de Nuestra Señora de Gracia, Ramón y Cajal, 60, 50004 Zaragoza, Spain Email rlozano@salud.aragon.es 
Toll-interleukin-1 receptor domain-containing adaptor molecule-1 (TICAM-1), which also harbors a proline-rich region. ${ }^{4}$

2. Receptor "clustering" at the immune synapse in memory B cells is mediated by the postsynaptic density-95/ disc large/zona occludens-1 (PDZ) domain of synapseassociated protein-97 (SAP97), which is a carrier protein that contains $\mathrm{SH} 3$ domains to mediate protein-protein interactions via proline-rich sequences (XPpXP). ${ }^{5}$

Therefore, genetic alterations (ie, SNPs), which can be found within intronic and intergenic regions of the genome in schizophrenic patients, might exist within ncRNAs that are involved in genetic replication, transcription, and translation. These ncRNAs may also participate in DNA transposition (RNA-mediated) and/or splicing events, which could yield deleterious effects on proline-containing proteins. ${ }^{6,7}$

\section{Disclosure}

The authors report no conflicts of interest in this work.

\section{References}

1. Need AC, Ge D, Weale ME, et al. A genome-wide investigation of SNPs and CNVs in schizophrenia. PLoS Genet. 2009;5(2):e1000373.

2. Watson JD, Baker TA, Bell SP, Gann A, Levine M, Oosick R. Molecular Biology of the Gene. San Francisco, CA: Pearson PLC; 2008:522.

3. Perkins DO, Jeffries C, Sullivan P. Expanding the 'central dogma': the regulatory role of nonprotein coding genes and implications for the genetic liability to schizophrenia. Mol Psychiatry. 2005;10(1):69-78.

4. Hutchinson MR, Northcutt AL, Hiranita T, et al. Opioid activation of toll-like receptor 4 contributes to drug reinforcement. J Neurosci. 2012;32(33):11187-11200.

5. Liu W1, Chen E, Zhao XW, et al. The scaffolding protein synapseassociated protein 97 is required for enhanced signaling through isotypeswitched IgG memory B cell receptors. Sci Signal. 2012;5(235):ra54.

6. Bundo M, Toyoshima M, Okada Y, et al. Increased 11 retrotransposition in the neuronal genome in schizophrenia. Neuron. 2014;81(2):306-313.

7. Kaalund SS, Newburn EN, Ye T, et al. Contrasting changes in DRD1 and DRD2 splice variant expression in schizophrenia and affective disorders, and associations with SNPs in postmortem brain. Mol Psychiatry. December 10, 2013. [Epub ahead of print].
Neuropsychiatric Disease and Treatment

\section{Publish your work in this journal}

Neuropsychiatric Disease and Treatment is an international, peerreviewed journal of clinical therapeutics and pharmacology focusing on concise rapid reporting of clinical or pre-clinical studies on a range of neuropsychiatric and neurological disorders. This journal is indexed on PubMed Central, the 'PsycINFO' database and CAS,

\section{Dovepress}

and is the official journal of The International Neuropsychiatric Association (INA). The manuscript management system is completely online and includes a very quick and fair peer-review system, which is all easy to use. Visit http://www.dovepress.com/testimonials.php to read real quotes from published authors. 